\title{
Recidivující chronické infekce močových cest (RIMC) - stará diagnóza a nová fakta
}

Na 16. konferenci Interní medicína pro praxi vysílaném on-line z Olomouce 30. dubna 2021 zazněla přednáška MUDr. Jiřího Emmera věnovaná recidivujícím (chronickým) infekcím močových cest. MUDr. Emmer ve své přednášce nejen vysvětlil etiopatogenezi, jejíz pochopení je zásadní pro správné vedení terapie, ale velmi přehledně shrnul i možnosti léčby recidivujících močových infekcí konvenčními i alternativními léčebnými režimy.

\section{Akutní cystitida, rekurentní cystitida a intersticiální cystitida (bladder pain syndrome)}

Močové infekce postihují zejména ženy, přičemž nejčastějším pưvodcem močových infekcí je Escherichia coli. Akutní a rekurentní cystitida, stejně tak jako intersticiální cystitida, mají obdobné klinické př́znaky, přičemž ale mezi těmito klinickými jednotkami jsou zásadní rozdíly a pro komplexní pochopení problematiky močových infekcí a následně i pro správnou volbu terapie je nezbytné se ve výše uvedených třech klinických jednotkách dobře orientovat.

Akutní cystitida je onemocnění způsobené zevním zdrojem infekce, v klinickému obrazu dominuji dysurie, urgentní mikce, může být prítomna hematurie a u jednotlivých pacientek je pak různě vyjádřená i bolest, jejíz tíže však nekoreluje s významností (tíží) bakteriurie. Léčba akutní močové infekce je krátkodobá, 5 až 7 dnů.

Rekurentní cystitida je na rozdíl od cystitidy akutní způsobena endogenní infekcí, tedy zdrojem jsou bakterie perzistující v urotelu močových cest a pro klinický obraz rekurentní cystitidy je typické kolísání závažnosti obtiží v čase, kdy se u pacientky různě střídají zcela asymptomatická období s periodami mírných obtiží, které samy odezní nebo přejdou v plně vyjádřený infekt močových cest. Pro odlišení cystitidy akutní a rekurentní je zásadní odběr anamnézy - aktivně se ptáme na předešlé infekty močových cest a cíleně je v anamnéze vyhledáváme. V prípadě, že u pacientky jde o druhý močový infekt v posledních šesti měsících či třetí močový infekt v posledním roce, jedná se o rekurující onemocnění, kdy po zaléčení právě běžícího uroinfektu musíme navázat léčbou dlouhodobou - profylaktickou.

Intersticiální cystitida, neboli bladder pain syndrom (BPS) - syndrom bolestivého močového měchýře, je onemocnění klinicky se manifestující urgentní mikcí, polakisurií, močením menších porcí moči a chronickou bolestí, přičemž ale tyto obtí̌e již nejsou způsobeny floridní infekcí močových cest. Etiologie rozvoje BPS je nejasná, předpokládá se jistá predispozice konkrétního člověka daná geneticky a současně kontakt s konkrétním uropatogenním kmenem E. coli, který je vybaven specifickým O antigenem. Léčba BPS je zatím velmi svízelná, z pokusů na zvírecích modelech se zvažuje využití ranitidinu či aprepitantu.

Mezi výše uvedenými klinickými jednotkami existuje jistá souvislost, nebot’ akutní cystitida může prejít v cystitidu rekurentní a pro rozvoj cystitidy intersticiální je s nejvyšší pravděpodobností nutné prodělat alespoň jednu akutní močovou infekci. Dle klinické studie provedené na dvojčatech může průběh první močové infekce předurčovat senzibilizaci k dalším infekcím močových cest. Na myších modelech bylo prokázáno, že pokud při první akutní cystitidě dojde k nadměrné aktivaci imunitní odpovědi, může dojít k poškození urotelu a změněně exprese některých signálních molekul na povrchu buněk s následnou senzibilizací k další uroinfekci. Tato hypotéza pak byla podpořena i výsledky klinické studie provedené na ženách, které prodělaly akutní močovou infekci.

Dle myších modelů je předpoklad možnosti ovlivnění imunologické reakce na akutní cystitidu, přičemž príznivé modulace premrštěné imunologické odpovědi v akutní fázi infekce mưžeme dosáhnout pomocí podávání nesteroidních antiflogistik či D-manózy, která zasahuje do produkce IL-1 $\beta$ a diferenciace T-lymfocytů.

\section{Rekurentní uroinfekce (RIMC) - etiopatogeneze a terapie}

Více než 80 \% prípadů RIMC je způsobeno uropatogenním kmenem E. coli, tedy kmenem, který je geneticky předurčen k adhezi na povrch urotelu s možností následné invaze do jeho hlubších vrstev - faktory virulence a patogenity těchto kmenů E. coli jsou adheziny a invaziny, díky kterým bakterie adherují k D-manóze v uroplakinu (ochranné vrstvě) na luminálním pólu epitelu močových cest, čímž usnadňují adherenci bakterie k epitelu močových cest a její perzistenci v močových cestách po mikci. Invaziny pak uropatogennímu kmeni E. coli umožňují prostup buněčnou membránou urotelu do intracelulárního prostoru a umožňuji ji „ukrýt" se uvnitř buňky před sérovými hladinami řady antibiotik. Uvnitř buněk je bakterie schopna i dalšího množení a zakládání tzv. intracelulárních bakteriálních komunit. Takto zasažené buňky prodělají apoptózu, čímž dochází k uvolnění intracelulárních bakteriálních komunit do moči. Některé bakterie díky invazinům pronikají dokonce až do buněk v bazálních vrstvách epiteliální výstelky močových cest, kde intracelulárně, mimo dosah chemoterapeutik, zakládají tzv. spící ložiska. Spící ložiska v bazální vrstvě epitelu jsou rezervoárem pro reinfekci, ke které zřejmě dochází v prípadě príhodných podmínek (stres, koitus apod.). Působení vhodných zevních faktorů totiž může odstartovat replikaci a množení doposud spících bak- 


\section{ZAZNĚLO NA 16. KONFERENCI INTERNÍ MEDICÍNA PRO PRAXI}

RECIDIVUJIĆĆ CHRONICKÉ INFEKCE MOČOVÝCH CEST(RIMC) - STARÁ DIAGNÓZA A NOVÁ FAKTA

terií. Tento mechanismus vysvětluje, proč je až 75 \% RIMC způsobeno týmž bakteriálním kmenem, který vyvolal předchozí uroinfekci.

V terapii RIMC můžeme využívat dlouhodobé subinhibiční antibiotické režimy (nitrofurantoin, sulfamethoxazol-trimethoprim) či alternativní režimy založené zejména na D-manóze a lyzátech, ne však brusinkách. účinnost jednotlivých léčebných režimů se značně liší, při užití podávání subinhibičních dávek nitrofurantoinu dosahujeme při šestiměsiční terapii pacientek s RIMC úspěšnosti kolem $80 \%$, při využití sulfamethoxazolu-trimethoprimu pak kolem 59\%, což je dáno rychlejším rozvojem rezistence k terapii sulfamethoxazolem-trimethoprimem oproti nitrofurantoinu. Z alternativních režimů léčby rekurentní močové infekce pak při šestiměsíční terapii dosahuje nejlepších výsledků D-manóza, jejiž účinnost je srovnatelná s účinností nitrofurantoinu podávaném v subinhibičních dávkách (85\%). Účinnost bakteriálních lyzátů při šestiměsíční terapii RIMC se pohybuje kolem $60 \%$. Režimy založené na brusinkách vykazují účinnost v profylaxi RIMC srovnatelnou s placebem, a proto nejsou vhodné (viz např. německé guideliny 2017-22).

D-manóza je metabolicky neutrální sacharid, který se filtruje do moči a v močových cestách se váže na adheziny prítomných bakterií. Obsazením těchto faktorů virulence dochází de facto k jejich blokádě, čímž je zabráněno adhezi bakterií k vrstvě uroplakinu na endoluminálním pólu buněk epitelu močových cest. D-manóza tak znemožňuje jeden ze zásadních dějů, který je nutný pro rozvoj močové infekce. D-manóza je velmi dobře tolerována, její snášenlivost je na úrovni placeba, a vzhledem k tomu, že D-manóza není antibiotikum ani chemoterapeutikum, tak její použití není spojeno s rozvojem střevní či vaginální dysmikrobie a pochopitelně ani s rozvojem rezistence $k$ antibiotikům. I z těchto důvodů je využití D-manózy a lyzátů v léčbě RIMC dle německých doporučení upřednostňováno před dlouhodobým podáváním antibiotik. Dle těchto doporučení je rovněž vhodné léčbu doplnit o vaginální probiotika a lokální estrogeny $\checkmark$ prípadě postmenopauzálních žen.

\section{Závěr}

Močové infekce jsou častou problematikou nejen v primární péči. S uroinfekcemi se setkáváme zejména u žen, část našich pacientek se nám bohužel do ambulance s touto problematikou opakovaně vrací. Léčba akutní močové infekce povětšinou nečiní větší obtíže, složitější je ale problematika infekcí recidivujících, kdy dochází k opakovaným endogenním reinfekcím - zdrojem recidiv uroinfektů jsou v naprosté většině prípadů kmeny uropatogenní E. coli, které perzistují v bazálních vrstvách urotelu jako "spící ložiska”, která se v príhodnou dobu „probudí" a začnou se replikovat. Zcela zásadní pro budoucí úspěch léčby recidivující močové infekce je její rozpoznání. Cíleně se pacientky musíme ptát na močové obtiže v posledním roce a v prípadě, že pacientka prodělává již druhou uroinfekci za posledních šest měsíců, či třetí v posledním roce, nejedná se již o akutní, nýbrž o recidivující uroinfekci, která vyžaduje specifický léčebný režim založený na dlouhodobé profylaktické terapii. Po zaléčení akutních obtíži musíme u takovéto pacientky navázat dlouhodobou léčbou, která zabrání endogenní reinfekci. $\checkmark$ těchto dlouhodobých profylaktických režimech Ize využít antibiotika (nitrofurantoin či sulfamethoxazol-trimethoprim) nebo režimy alternativní založené na využití zejména D-manózy a bakteriálních lyzátů. Z hlediska účinnosti Ize srovnat dlouhodobé užívání nitrofurantoinu v subinhibiční dávce s využitím D-manózy (účinnost kolem $80 \%$, resp. $85 \%$ u D-manózy) a režim s užitím sulfamethoxazolu-trimethoprimu s režimem založeným na lyzátech (59\% versus $65 \%$ ). Zcela nevhodné je naopak v této indikaci využití extraktů z brusinek, jejichž účinnost je srovnatelná s placebem. Každé využití antibiotik je spojeno s rizikem nežádoucích účinků, a i proto je např. v německých doporučených postupech pro terapii rekurentní močové infekce upřednostněno využití léčebných režimů založených na podávání D-manózy a bakteriálních lyzátů před režimy užívajících podávání antibiotik. Léčbu RIMC je dle těchto doporučení vhodné doplnit o vaginální probiotika a lokální estrogeny u postmenopauzálních žen. Léčba D-manózou je bezpečná a velmi dobře tolerovaná, její snášenlivost je rovna snášenlivosti placeba. Při terapii D-manózou nedochází k ovlivnění střevní ani vaginální mikroflóry a nehrozí ani rozvoj bakteriální rezistence k antibiotikům. D-manóza je metabolicky neutrální sacharid, který proniká do moči, kde se váže na adheziny přítomných bakterií, čímž brání adherenci bakterií k epitelu močových cest, a tedy rozvoji močové infekce. Již radu let v praxi využíváme kombinovaný preparát Blokurima URO+, který obsahuje jak D-manózu, tak i bakteriální lyzáty, čímž kombinuje hned dva alternativní režimy léčby RIMC, které mají prokázanou vysokou účinnost. Z doporučovaných vaginálních probiotik k úpravě poševní mikroflóry Ize využít např. prípravek Gynimun intim protect.

MUDr. Pavel Rutar Interní oddělení Nemocnice Na Homolce 